\title{
Faktor Risiko Diare Shigellosis pada Anak Balita
}

\author{
Risk Factors of Shigellosis Diarrhea in Children Under Five Years Old
}

\author{
A. Zulkifli Abdullah, A. Arsunan Arsin, Lidyawati Dahlan
}

\section{Bagian Epidemiologi Fakultas Kesehatan Masyarakat Universitas Hasanuddin}

\begin{abstract}
Abstrak
Diare shigellosis pada balita merupakan masalah serius sebab dapat menyebabkan kematian. Untuk mengetahui faktor-faktor risiko kejadian shigellosis pada anak balita dilakukan studi kasus kontrol di beberapa rumah sakit di Kota Makassar dengan 68 kasus dan 136 kontrol. Data mengenai jenis kelamin dan status gizi anak balita, pemberian air susu ibu (ASI) eksklusif, status ekonomi, pendidikan ibu, kebiasaan ibu mencuci tangan memakai sabun, kepadatan hunian rumah, sarana air bersih, dan jamban keluarga dikumpulkan dengan wawancara dan observasi serta dikategorikan dan disaring (screening) dengan uji chi square. Enam variabel dengan nilai $p<0,25$ dimasukkan dalam uji regresi logistik yang menghasilkan 3 variabel dengan nilai $p<0,05$ (gizi rendah, ASI tidak eksklusif, dan status ekonomi rendah). Uji regresi logistik tahap kedua dengan 3 variabel ini menghasilkan model shigellosis $=1,47$ gizi rendah $+1,471 \mathrm{ASI}$ tidak eksklusif $+1,022$ status ekonomi rendah $-2,546$ " dengan nilai odds ratio $(O R)=4,352$ (gizi rendah), 4,353 (ASI tidak eksklusif), dan 2,779 (status ekonomi rendah). Studi ini menyimpulkan bahwa gizi balita yang rendah, pemberian ASI yang tidak eksklusif, dan status ekonomi ibu yang rendah merupakan faktor-faktor risiko penting kejadian diare shigellosis pada balita.
\end{abstract}

Kata kunci: Balita, diare, shigellosis, status gizi

\footnotetext{
Abstract

Shigellosis diarrhea is a serious issue to children under five years old since it may lead to death. To determine the risk factors influence to children under five shigellosis, a case control study conducted in hospitals in Makassar involving 68 cases and 136 controls. Data on sex, nutrition status of children under five, exclusive breastfeeding, economic status, education, hand washing with soap, house density, clean water facility, and toilet were collected by interview and observation. All collected data were categorized and screened using chi-square test to obtain variables for logistic regression. Six variables with $p$ value $<0,25$ were putted to logistic regression resulted 3
}

variables with $p$ value $<0,05$ (low nutrition status, $p$ value $=0,00$; nonexclusive breastfeeding, $p$ value $=0,00$; low economic status of mother, $p$ value $=0,00$ ). These variables gave final model of "shigellosis $=1,47 \mathrm{low}$ nutrition status $+1,471$ nonexclusive breastfeeding $+1,022$ low economic status $-2,546$ " with odds ratio $(O R)=4,352$ (low nutrition status), 4,353 (nonexclusive breastfeeding), and 2,779 (low economic status of mother). This study concludes that low nutrition status, nonexclusive breastfeeding, and low economic status of mother are important risk factors of shigellosis in children under five.

Key words: Children under five, diarrhea, logistic regression, shigellosis, nutrition status

\section{Pendahuluan}

Diare merupakan salah satu penyebab utama kematian, terutama pada anak-anak. Sekitar 10\% episode diare pada anak berusia di bawah lima tahun (balita) di seluruh dunia merupakan diare berdarah atau disentri. Dari seluruh kematian balita akibat diare, 15\% berhubungan dengan diare berdarah. ${ }^{1}$ Di Indonesia, salah satu jenis disentri adalah shigellosis yang disebabkan oleh kuman Shigella spp. ${ }^{2}$

Shigellosis merupakan diare yang ditandai dengan tinja yang berdarah dan berlendir disertai dengan gejala demam dan gembung (meteorismus). Spektrum klinis shigellosis cukup luas, mulai dari diare cair, diare berdarah, diare persisten, dan gejala lain di luar sistem pencernaan sebagai komplikasi akibat infeksi Shigella spp. Penyebaran Shigella spp terjadi secara feko-oral,

Alamat Korespondensi: A. Zulkifli Abdullah, Bagian Epidemiologi FKM Universitas Hasanuddin, Jl. Perintis Kemerdekaan Km. 10 Tamalanrea Makassar 90245, Hp.081342706750,e-mail: zulkifliabdullah@yahoo.com 
terutama dari orang ke orang melalui tangan yang terkontaminasi tinja. Kuman ini sangat infeksius sehingga seseorang dapat menjadi sakit apabila terinfeksi oleh 10 100 kuman. $^{3}$

Selama tahun 2007, di Provinsi Sulawesi Selatan tercatat 209.435 kasus. Menurut kelompok umur, diare paling banyak terjadi pada balita dengan 93.560 kasus. Tahun 2008, jumlah diare menurun sedikit menjadi 209.153 kasus, Kota Makassar tertinggi (45.929 kasus) dan Kabupaten Enrekang terendah (400 kasus). Namun, tahun 2009 kejadian diare meningkat lagi menjadi 226,961 kasus dengan Kota Makassar masih yang tertinggi (45.014 kasus). ${ }^{4}$

Menurut data rekam medik di beberapa rumah sakit di Kota Makassar, proporsi kasus shigellosis pada balita cenderung meningkat dalam beberapa tahun terakhir. Tahun 2008, kejadian shigellosis pada balita rawat inap di Rumah Sakit Umum Pemerintah (RSUP) Wahidin Sudirohusodo tercatat 26 kasus $(11,1 \%)$ dari 208 kasus diare, turun sedikit menjadi 24 kasus $(11 \%)$ dari 218 kasus diare pada tahun 2009, dan naik lagi menjadi 37 $(7,4 \%)$ dari 175 kasus diare pada tahun 2010. Tahun 2010, 1.218 kasus diare tercatat di Rumah Sakit (RS) Labuang Baji dan 593 kasus di Rumah Sakit Umum (RSU) Daya. Catatan ini menggambarkan bahwa di kota Makassar kasus diare masih cukup tinggi, namun data shigellosis sangat terbatas bahkan tidak teridentifikasi.

Diare shigellosis pada anak balita merupakan masalah serius karena manifestasinya cukup berat akibat komplikasi yang dapat menyebabkan kematian. ${ }^{3}$ Gangguan nutrisi merupakan salah satu faktor risiko kejadian diare shigellosis, sehingga peran ibu dan anggota keluarga dalam menyiapkan makanan sehat dan bergizi serta cara memberi makan anak balita menjadi sangat penting. 5,6 Oleh karena itu, untuk menanggulangi masalah shigellosis perlu dilakukan identifikasi faktor-faktor risiko meliputi karakteristik demografi dan status gizi anak balita, sosiodemografi ibu, higiene perorangan ibu, higiene dan sanitasi tempat tinggal, serta kualitas sarana kesehatan lingkungan.

\section{Metode}

Penelitian ini menggunakan rancangan studi kasus kontrol. Sampel ditarik secara purposif di 5 rumah sakit di Kota Makassar (RSUP Wahidin Sudirohusodo, RS Labuang Baji, RS Ibnu Sina, Rumah Sakit Islam (RSI) Faisal, dan RSU Daya). Dengan cara ini diperoleh 68 kasus shigellosis yang dipilih dari pasien rawat inap diare berdasarkan pemeriksaan laboratorium dengan leukosit tinja $\geq 10 /$ limfosit plasma biru (LPB). Kontrol dengan umur balita berjumlah 136, dipilih dari balita tanpa diare yang tempat tinggalnya berdekatan dengan kasus.

Data mengenai demografi (umur, berat badan, tinggi badan, dan jenis kelamin) dan status gizi anak balita, pemberian air susu ibu (ASI) eksklusif, status ekonomi ibu, pendidikan ibu, kebiasaan cuci tangan, kepadatan hunian rumah, sarana air bersih, dan jamban keluarga dikumpulkan dengan wawancara menggunakan kuesioner terstruktur dan observasi. Data dikumpulkan dari tanggal 16 Februari 2011 hingga 30 April 2011.

Semua data yang terkumpulkan ditabulasi dalam skala kategorik. Status gizi balita dikategorikan menggunakan penggolongan Waterlow berdasarkan rasio berat badan terhadap tinggi badan menjadi gizi buruk (< $70 \%)$, gizi kurang $(70 \%-90 \%)$, dan gizi baik $(90 \%-$ $110 \%) .{ }^{7}$ Untuk penentuan nilai odds ratio (OR), semua variabel dikategorikan secara dikotomis menjadi risiko rendah dan risiko tinggi. Kriteria untuk menetapkan kategori ini yaitu dikatakan kasus diare shigellosis bila balita yang menderita diare buang air besar (BAB) 3 kali atau lebih dengan perubahan konsistensi tinja lunak atau encer dan dalam pemeriksaan tinja, leukosit $\geq 10 / \mathrm{LPB}$ yang tercatat di bagian rekam medis beberapa rumah sakit di Makassar sedangkan kontrol adalah balita yang tidak menderita diare dan tinggal berdekatan rumah dengan kasus. Dikatakan risiko tinggi bila jenis kelamin laki-laki, status gizi $<90 \%$ berdasarkan hasil pengukuran berat badan (BB) dan tinggi badan yang ditentukan dengan rumus BB aktual/BB ideal dikalikan 100\%, tidak mendapatkan ASI eksklusif (0 - 6 bulan), pendapatan keluarga $<$ upah minimum regional (UMR), pendidikan formal ibu maksimal sekolah dasar (SD) atau tidak tamat sekolah lanjutan tingkat pertama (SLTP), tidak mencuci tangan menggunakan sabun sebelum menyiapkan atau memberi makan pada anak, luas bangunan untuk tiap anggota keluarga kurang dari $10 \mathrm{~m}^{2}$, menggunakan air yang tidak bersumber dari perusahaan air minum (PAM) untuk kebutuhan sehari-hari, serta tidak memiliki jamban atau memiliki jamban tetapi tidak bersih, berbau, dan tidak tertutup. ${ }^{8}$ Disebut risiko rendah bila jenis kelamin perempuan, status gizi 90\% - 110\%, mendapatkan ASI eksklusif, pendapatan keluarga $\geq$ UMR, pendidikan formal ibu minimal tamat SLTP (ada bukti ijazah), mencuci tangan dengan sabun sebelum menyiapkan makanan anak, luas bangunan $>10 \mathrm{~m}^{2}$, menggunakan air PAM untuk kebutuhan sehari-hari, dan memiliki jamban yang memenuhi syarat. Data yang terkumpul dianalisis untuk mendeskripsikan variabel-variabel yang diduga sebagai faktor risiko shigellosis kemudian dihitung nilai OR masing-masing. Selanjutnya, variabel dengan nilai $\mathrm{p}<0,25$ dimasukkan dalam pemodelan regresi logistik berganda. Model akhir ditetapkan dengan menyertakan variabel dengan nilai $\mathrm{p}<0,05$.

\section{Hasil}

Sebaran data diare shigellosis pada balita pasien rawat inap di RSUP Wahidin Sudirohusodo, RS Labuang 
Tabel 1. Proporsi Diare Shigellosis pada Balita

\begin{tabular}{lccccc}
\hline Kasus & $\begin{array}{l}\text { RSUP Wahidin } \\
\text { Sudirohusodo }\end{array}$ & RS Labuang Baji & RS Ibnu Sina & RSI Faisal & RSU Daya \\
\hline Shigellosis & 1 & 49 & 2 & 1 & 15 \\
\% shigellosis & 2 & 72 & 3 & 1 & 22 \\
\hline
\end{tabular}

Tabel 2. Karakteristik Balita dalam Studi Kasus Kontrol Diare Shigellosis

\begin{tabular}{|c|c|c|c|c|c|c|c|}
\hline \multirow{2}{*}{ Variabel } & \multirow{2}{*}{ Kategori } & \multicolumn{2}{|c|}{ Kasus } & \multicolumn{2}{|c|}{ Kontrol } & \multicolumn{2}{|c|}{ Jumlah } \\
\hline & & $\mathbf{n}$ & $\%$ & $\mathbf{n}$ & $\%$ & $\mathbf{n}$ & $\%$ \\
\hline \multirow[t]{3}{*}{ Umur } & $0-<1$ tahun & 36 & 52,9 & 72 & 52,9 & 108 & 52,9 \\
\hline & $1-<3$ tahun & 31 & 45,6 & 62 & 45,6 & 93 & 45,6 \\
\hline & $3-<5$ tahun & 1 & 1,5 & 2 & 1,5 & 3 & 1,5 \\
\hline \multirow[t]{2}{*}{ Jenis kelamin } & Laki-laki & 33 & 48,53 & 69 & 50,74 & 102 & 50 \\
\hline & Perempuan & 35 & 51,47 & 67 & 49,26 & 102 & 50 \\
\hline \multirow[t]{3}{*}{ Status gizi } & Gizi buruk & 10 & 14,7 & 0 & 0 & 10 & 4,9 \\
\hline & Gizi kurang & 39 & 57,3 & 44 & 32,4 & 83 & 40,7 \\
\hline & Gizi baik & 19 & 28,0 & 92 & 67,6 & 111 & 54,4 \\
\hline \multirow[t]{2}{*}{ ASI eksklusif } & Ya & 23 & 33,82 & 101 & 74,26 & 124 & 60,78 \\
\hline & Tidak & 45 & 66,18 & 35 & 25,74 & 80 & 39,22 \\
\hline \multirow[t]{5}{*}{ Pekerjaan orang tua (ayah) } & PNS & 1 & 1,5 & 17 & 12,5 & 18 & 8,8 \\
\hline & Swasta & 19 & 27,9 & 60 & 44,1 & 79 & 38,7 \\
\hline & Pedagang & 6 & 8,8 & 13 & 9,6 & 19 & 9,3 \\
\hline & Buruh & 28 & 41,2 & 34 & 25,0 & 62 & 30,4 \\
\hline & Lain-lain & 14 & 20,6 & 12 & 8,8 & 26 & 12,8 \\
\hline \multirow[t]{5}{*}{ Pendidikan ibu } & Tidak tamat SD & 1 & 1,47 & 17 & 12,50 & 18 & 8,82 \\
\hline & Tamat SD & 21 & 30,88 & 32 & 23,53 & 53 & 25,98 \\
\hline & SLTP & 26 & 38,24 & 25 & 18,38 & 51 & 25,0 \\
\hline & SLTA & 19 & 27,94 & 52 & 38,24 & 71 & 34,8 \\
\hline & Akademi/PT & 1 & 1,47 & 10 & 7,35 & 11 & 5,39 \\
\hline
\end{tabular}

Baji, RS Ibnu Sina, RSI Faisal, dan RSU Daya tercantum dalam Tabel 1. Tabel 2 menampilkan data mengenai karakteristik demografi (umur dan jenis kelamin) serta status gizi anak balita. Tabel 3 menyajikan hasil uji chi square faktor-faktor risiko dengan shigellosis $(\alpha=5 \%)$ sebagai tahap screening untuk analisis regresi logistik dengan persamaan umum logit $(\mathrm{Y})=\mathrm{a}+\mathrm{b}_{1} \mathrm{X}_{1}+\mathrm{b}_{2} \mathrm{X}_{2}+$ $\ldots .+b_{k} X_{k}$.

Berdasarkan 9 variabel yang diuji, hanya 6 variabel dengan nilai $\mathrm{p}<0,25$ yang dapat menjadi kandidat variabel regresi logistik yaitu gizi rendah, bukan ASI eksklusif, status ekonomi rendah, mencuci tangan tidak memakai sabun, kepadatan hunian $<10 \mathrm{~m}^{2}$ /orang, dan tidak memiliki jamban keluarga. Uji regresi logistik dengan 6 variabel tersebut menghasilkan 3 variabel dengan nilai $p$ $<0,5$ (gizi rendah, ASI tidak eksklusif, status ekonomi rendah) dan 3 variabel dengan nilai $p>0,05$. Dengan demikian, variabel mencuci tangan tidak memakai sabun, kepadatan hunian $<10 \mathrm{~m}^{2}$ /orang, dan tidak memiliki jamban keluarga dikeluarkan dari model. Parameter penting hasil uji regresi logistik dengan 3 variabel yang tersisa disajikan dalam Tabel 4.

Berdasarkan hasil uji regresi logistik model yang di dapat dapat dilihat pada Persamaan 1. Model ini tidak men- guji kemungkinan interaksi antarvariabel dan keberadaan variabel confounding.

\section{Pembahasan}

Tabel 1 menunjukkan bahwa kasus diare shigellosis terbanyak ditemukan di RS Labuang Baji, sedangkan terendah di RSUP Wahidin Sudirohusodo. Temuan ini dapat dipahami karena RS Labuang Baji merupakan rumah sakit rujukan setelah puskesmas. Di samping itu, RS Labuang Baji juga menerima pasien asuransi kesehatan keluarga miskin (Askeskin) dan jaminan kesehatan daerah (Jamkesda). Ternyata sebagian besar pasien diare shigellosis yang berobat atau dirujuk ke rumah sakit adalah peserta Askeskin maupun Jamkesda. Sebaliknya, RSUP Wahidin Sudirohusodo merupakan pusat rujukan yang menerima pasien dengan kasus berat yang tidak tertangani di rumah sakit lain di Kota Makassar sehingga wajar jika kasus diare shigellosis di rumah sakit ini sedikit. Rumah sakit ini juga merupakan pelayan kesehatan rujukan tingkat provinsi untuk wilayah Indonesia Timur.

Dibandingkan dengan kejadian di wilayah lain di Indonesia, shigellosis di Kota Makassar termasuk cukup tinggi. Surveillance yang dilakukan di Jakarta Utara pada 
Tabel 3. Ringkasan Statistik Chi Square

\begin{tabular}{|c|c|c|c|c|c|c|c|c|}
\hline \multirow{2}{*}{ Variabel } & \multirow{2}{*}{ Kategori } & \multicolumn{2}{|c|}{ Kasus } & \multicolumn{2}{|c|}{ Kontrol } & \multirow{2}{*}{ OR } & \multirow{2}{*}{ Nilai p } & \multirow{2}{*}{ CI 95\% } \\
\hline & & $\mathbf{n}$ & $\%$ & $\mathbf{n}$ & $\%$ & & & \\
\hline \multirow[t]{2}{*}{ Jenis kelamin balita } & Risiko tinggi & 33 & 48,5 & 69 & 50,7 & 0,91 & 0,76 & $0,49-1,70$ \\
\hline & Risiko rendah & 35 & 51,7 & 67 & 49,3 & & & \\
\hline \multirow[t]{2}{*}{ Status gizi balita } & Risiko tinggi & 49 & 72,1 & 44 & 32,4 & 5,39 & 0,00 & $2,72-10,82$ \\
\hline & Risiko rendah & 19 & 27,9 & 92 & 67,6 & & & \\
\hline \multirow[t]{2}{*}{ ASI eksklusif balita } & Risiko tinggi & 45 & 66,2 & 35 & 25,7 & 5,64 & 0,00 & $2,86-11,18$ \\
\hline & Risiko rendah & 23 & 33,8 & 101 & 74,3 & & & \\
\hline \multirow[t]{2}{*}{ Status ekonomi ibu balita } & Risiko tinggi & 38 & 55,9 & 37 & 27,2 & 3,38 & 0,00 & $1,76-6,52$ \\
\hline & Risiko rendah & 30 & 44,1 & 99 & 72,8 & & & \\
\hline \multirow{2}{*}{ Pendidikan ibu balita } & Risiko tinggi & 22 & 32,4 & 49 & 36,0 & 0,8 & 0,8 & $0,43-1,63$ \\
\hline & Risiko rendah & 46 & 67,6 & 87 & 64,0 & & & \\
\hline \multirow[t]{2}{*}{ Ibu balita mencuci tangan } & Risiko tinggi & 22 & 32,4 & 20 & 14,7 & 2,77 & 0,00 & $1,30-5,89$ \\
\hline & Risiko rendah & 46 & 67,6 & 116 & 85,3 & & & \\
\hline \multirow[t]{2}{*}{ Kepadatan hunian rumah } & Risiko tinggi & 43 & 63,2 & 59 & 43,4 & 2,24 & 0,00 & $1,18-4,28$ \\
\hline & Risiko rendah & 25 & 36,8 & 77 & 56,6 & & & \\
\hline \multirow[t]{2}{*}{ Sarana air bersih rumah } & Risiko tinggi & 23 & 33,8 & 42 & 30,9 & 1,14 & 0,67 & $0,58-2,21$ \\
\hline & Risiko rendah & 45 & 66,2 & 94 & 69,1 & & & \\
\hline \multirow[t]{2}{*}{ Jamban keluarga } & Risiko tinggi & 15 & 22,1 & 19 & 14,0 & 1,74 & 0,14 & $0,75-3,92$ \\
\hline & Risiko rendah & 53 & 77,9 & 117 & 86,0 & & & \\
\hline
\end{tabular}

Tabel 4. Ringkasan Statistik Regresi Logistik

\begin{tabular}{lccccc}
\hline Faktor Risiko & Koefisien $\left(\mathbf{b}_{\mathbf{1}} \mathbf{- 4}\right)$ & $\mathbf{z}$ & OR & 95\% CI & Nilai $\mathbf{p}$ \\
\hline Gizi rendah & 1,470 & 4,15 & 4,352 & $2,174-8,715$ & 0,000 \\
ASI tidak eksklusif & 1,471 & 4,20 & 4,354 & $2,192-8,646$ & 0,000 \\
Status ekonomi rendah & 1,022 & 2,89 & 2,779 & $1,389-5,558$ & 0,004 \\
\hline Konstanta (a) & $-2,546$ & & & &
\end{tabular}

Persamaan 1.

$\mathrm{Y}=1,47 \mathrm{x}_{1}+1,471 \mathrm{x}_{2}+1,0$
Keterangan :
$\mathrm{Y}=$ diare Shigellosis
$\mathrm{X} 1=$ status gizi rendah
$\mathrm{X} 2=$ ASI tidak eksklusif
$\mathrm{X} 3=$ status ekonomi rendah

periode bulan Agustus tahun 2001 sampai dengan bulan Juli tahun 2003 ditemukan insiden shigellosis pada anak umur $1-2$ tahun yaitu 32 per 1.000 balita per tahun. ${ }^{9}$ Surveillance yang dilaksanakan di Jakarta Selatan periode bulan Februari tahun 2005 sampai dengan bulan September tahun 2007 pada anak umur 0 - 14 tahun menemukan $63,2 \%(36 / 57)$ pasien diare adalah infeksi shigella. ${ }^{10}$

Menurut karakteristik demografi, hampir semua balita yang mengalami shigellosis berusia 0 sampai $<3$ tahun. Hal ini seperti yang dilaporkan oleh Aqtini MD, ${ }^{9}$ yang menemukan insiden diare shigellosis tinggi pada kelompok umur $1-2$ tahun.

Persamaan regresi logistik yang diperoleh dapat digunakan untuk menentukan probabilitas kejadian diare shigellosis pada subjek dengan kategori berisiko tinggi (nilai 1) dan berisiko rendah (nilai 0).

Persamaan regresi logistik hasil uji regresi tahap kedua merupakan hasil substitusi nilai variabel faktor risiko dengan kategori risiko tinggi (nilai 1) untuk status gizi rendah, ASI noneksklusif, dan status ekonomi rendah. Dengan fungsi probabilitas tersebut, kemungkinan kejadian shigellosis dapat diestimasi. Misalnya, probabilitas kejadian diare shigellosis pada anak balita yang mempunyai status gizi rendah, bukan ASI eksklusif, dan status ekonomi rendah adalah $80,5 \%$.

Sebaliknya, probabilitas kejadian diare shigellosis pada anak balita risiko rendah (nilai 0 untuk status gizi baik, ASI eksklusif, status ekonomi tinggi) adalah 7,2\%.

Studi tentang diare shigellosis masih sangat terbatas dan secara epidemiologi belum pernah dilakukan di Kota Makassar. Beberapa faktor risiko diare shigellosis dapat berinteraksi dalam menimbulkan diare shigellosis melalui proses yang kompleks mulai dari faktor agent, host, maupun environment. ${ }^{10}$

Dalam kejadian diare shigellosis ini ditemukan bahwa proporsi laki-laki dan perempuan tidak berbeda secara bermakna (nilai $\mathrm{p}=0,76$ ). Pada anak balita, jenis ke- 
lamin bukan merupakan faktor risiko diare shigellosis, namun jenis kelamin laki-laki bersifat protektif terhadap kejadian diare shigellosis $(\mathrm{OR}=0,91)$. Menurut studi ini, kebanyakan kasus shigellosis dialami oleh anak $<1$ tahun. Pada usia tersebut, biasanya anak belum banyak melakukan aktivitas fisik dan orang tua masih sangat protektif terhadap anaknya.

Status gizi sering berinteraksi dengan kejadian diare dan diare sering menyebabkan penurunan status gizi, terutama akibat infeksi yang disebabkan oleh kuman Shigella. ${ }^{5}$ Hasil penelitian ini menegaskan kembali pernyataan tersebut bahwa sebagian besar penderita shigellosis berstatus gizi kurang yaitu 57,3\% pada kasus sedangkan pada kontrol hanya $32,4 \%$. Penurunan status gizi pada kelompok kasus diduga kuat karena episode diare yang berulang. Hal ini yang membedakan antara diare shigellosis dengan diare biasa. Bila anak yang menderita diare shigellosis tidak diobati dengan tuntas, episode diare cenderung akan berulang akibat resistensi kuman terhadap berbagai antibiotik. 10,11

Status gizi buruk dan gizi kurang pada kasus diduga karena diare berlangsung lama (kronis dan persisten). Sementara itu, orangtua tidak mengerti tentang penatalaksanaan diare, bahkan sebagian mereka menganggap bahwa shigellosis yang diderita anaknya adalah diare biasa sehingga anak tidak segera dibawa ke rumah sakit. Tidak sedikit orangtua baru membawa anaknya ke rumah sakit ketika si anak sudah kejang-kejang, bahkan waktu kesadarannya sudah menurun. Menurut model regresi logistik yang didapat, gizi kurang merupakan faktor risiko shigellosis yang kontribusinya sama besar dengan ASI noneksklusif $(\alpha=0,000)$.

Kebanyakan ibu responden pada kelompok kasus tidak memberikan ASI eksklusif (66,18\%). Sebagian mereka memberikan susu formula, sedangkan beberapa ibu responden hanya memberikan air putih atau air teh sebagai pengganti susu kepada anak balitanya. Pada kelompok kontrol, terdapat lebih banyak ibu responden yang memberikan ASI eksklusif $(74,26 \%)$ daripada ASI noneksklusif. Keadaan ini berkaitan dengan status ekonomi ibu balita. ${ }^{12}$ Dalam model regresi yang didapat, status ekonomi rendah merupakan faktor risiko shigellosis, walaupun kontribusinya lebih rendah daripada gizi kurang dan ASI noneksklusif.

Status ekonomi yang rendah ditunjukkan oleh pekerjaan orang tua responden pada kelompok kasus. Pekerjaan terbanyak orangtua, dalam hal ini, ayah adalah buruh. Para orang tua penderita menyatakan bahwa dengan penghasilan yang pas-pasan mereka enggan membawa anaknya ke dokter karena biayanya mahal. Mereka memilih pengobatan lain seperti membawa anaknya ke dukun atau mengobati sendiri dengan memberikan ramuan tradisional. Cara ini dapat menyebabkan diare shigellosis tidak sembuh, bahkan kuman Shigella mene- tap dalam tubuh. Jika dibiarkan, diare tersebut menjadi persisten karena infeksinya tidak tertangani. ${ }^{11,13}$

Pekerjaan umumnya berhubungan dengan tingkat pendidikan. Menurut penelitian ini ternyata $32,4 \%$ ibu balita pada kelompok kasus berpendidikan rendah, separuh dari pendidikan ibu pada kelompok kontrol mencapai $67,6 \%$. Namun, pendidikan yang tinggi belum menjamin anak tidak terkena penyakit karena belum tentu pengetahuannya dipraktikkan. Kemungkinan lain adalah ibu balita belum mengetahui secara detail penyakit yang diderita oleh anaknya dan tidak berupaya mencari pengobatan secara rasional. Dalam model regresi, tingkat pendidikan ibu bukan faktor risiko diare shigellosis. Namun demikian, tingkat pendidikan ibu dapat memengaruhi perilaku hidup bersih dan sehat (PHBS) seperti perilaku mencuci tangan.

Salah satu PHBS yang dianjurkan oleh World Health Organization (WHO) adalah mencuci tangan memakai sabun sebelum menyiapkan atau memberi makan kepada balita. ${ }^{2}$ Hasil penelitian menunjukkan bahwa mencuci tangan dengan memakai sabun merupakan faktor risiko diare shigellosis pada anak balita (nilai $\mathrm{p}=0,00$ ), walaupun dalam model regresi akhir tidak termasuk sebagai variabel. Artinya, ibu responden belum mempraktikkan PHBS secara konsisten yakni belum mengikuti cara cuci tangan 7 langkah menurut WHO.

Kepadatan penghuni merupakan cara yang mudah untuk kontak langsung dengan orang yang sudah berpenyakit yang dapat menularkannya ke orang lain. Kepadatan hunian yang melebihi ketentuan dapat menyebabkan seluruh anggota keluarga terus terpapar dengan penyakit tanpa disadari. ${ }^{8}$ Anak-anak atau balita memiliki risiko lebih besar untuk sakit.5,6,13 Hasil penelitian menunjukkan bahwa penderita diare shigellosis tinggal dalam rumah dengan kepadatan penghuni $<10 \mathrm{~m}^{2}$ per jiwa, pada kelompok kasus lebih banyak daripada rumah yang tidak padat. Hunian yang padat memudahkan penghuni menderita suatu penyakit termasuk diare shigellosis. Meskipun mempunyai hubungan yang signifikan dengan shigellosis (nilai $\mathrm{p}=0,00$ ), dalam model regresi akhir kepadatan hunian bukan variabel. Apabila kepadatan hunian berinteraksi dengan variabel-variabel lain seperti status ekonomi rendah, status gizi kurang, dan ASI noneksklusif maka variabel ini akan semakin kuat memberikan efek penyakit.

Sarana air bersih dan jamban keluarga bukan merupakan faktor risiko diare shigellosis karena secara statistik keduanya tidak berhubungan secara bermakna (nilai $p=0,67$ dan 0,14$)$. Namun, sarana air bersih perlu tetap diwaspadai karena sarana air yang kotor dan tidak memenuhi syarat kesehatan merupakan media penyebaran penyakit. ${ }^{14,15}$ Di samping itu, air minum yang tidak dimasak juga dapat menjadi media penularan penyakit diare shigellosis. ${ }^{15}$ 


\section{Kesimpulan}

Penelitian ini menyimpulkan bahwa balita dengan status gizi kurang, tidak mendapatkan ASI eksklusif, dan status ekonomi ibu yang rendah merupakan faktor risiko kejadian diare shigellosis. Probabilitas kejadian shigellosis dapat diestimasi dari tingkat risiko rendah atau tinggi setiap variabel model regresi logistik.

\section{Saran}

Sesuai dengan model regresi logistik yang didapat, untuk mencegah shigellosis disarankan untuk meningkatkan status gizi balita berdasarkan pola makan sesuai umur serta kebutuhan kalori sehari-hari, memberikan ASI secara eksklusif sedini mungkin, dan meningkatkan status ekonomi orang tua melalui upaya tidak langsung dengan meningkatkan tingkat pendidikan.

\section{Daftar Pustaka}

1. World Health Organization. Guidelines for the control of shigellosis. Geneva: World Health Organization; 2005.

2. Direktorat Jendral Pengendalian Penyakit dan Penyehatan Lingkungan Kementerian Kesehatan Republik Indonesia. Shigellosis. Jakarta: Direktorat Jendral Pengendalian Penyakit dan Penyehatan Lingkungan Kementerian Kesehatan Republik Indonesia; 2005.

3. Ismail R. Diare bermasalah: shigellosis. Dalam Kongres Nasional II Badan Koordinasi Gastroenterologi Anak Indonesia; 2003; Bandung.

4. Dinas Kesehatan Sulawesi Selatan. Profil kesehatan dinas kesehatan Provinsi Sulawesi Selatan tahun 2008. Makassar: Dinas Kesehatan Sulawesi Selatan; 2009.

5. Dyah P, Setia BS, Dasril D. Khasiat probiotik pada shigellosis bayi dan anak dengan dehidrasi berat. Makassar: Bagian Ilmu Kesehatan Anak Fakultas Kedokteran Universitas Hasanuddin; 2010.

6. Masyuni. Implementasi program promosi pencegahan diare pada anak di bawah tiga tahun (studi kasus di Puskesmas Mangkurawang Kabupaten Kutai Kartanegara) [tesis]. Surakarta: Universitas Surakarta;
2010.

7. Centers for Disease Control and Prevention. Centers for disease control and prevention growth charts for the United State: methods and development, vital, and health statistics. 2002; 11 (246).

8. Hasnida. Crowding and density. In: Aqtini MD. The burden of diarrhoea, shigellosis, and cholera in North Jakarta, Indonesia: findings from 24 month surveillance. 2002 [cited 2012 June 6]. Available from: http://www.ncbi.nlm.nih.gov/ pubmed/16242013.

9. Atiqni MD, Soeharno R, Lesmana M, Punjabi NH, Simanjuntak C, Wangsasaputra F, et al. The burden of diarrhoea, shigellosis, and cholera in North Jakarta, Indonesia: findings from 24 month surveillance. BMC Infectious Diseases. 2005; 7:1 [cited 2012 June 6]. Available from: http://www.ncbi.nlm.nih.gov/ pubmed/16242013.

10. Herwana E, Surjawidjaja JE, Salim OCh, Indriani N, Bukitwetan P, Lesmana M. Shigella-associated diarrhea in children in South Jakarta, Indonesia. Southeast Asian Journal Tropical Medicine Public Health. 2010; 41 (2): 418-25 [cited 2012 June 6]. Available from: http://www. tm.mahidol.ac.th/seameo/2010-41-2/20-4601.pdf.

11. Dwipoerwantoro PG, Pulungsih SP, Susanti NI, Sadikin H, Firmansyah A. A study on the antibiotic resistance of shigella. 2005 [cited 2012 June 6]. Paediatrica Indonesiana; 45 (3 - 4). Available from: http://www.paediatricaindonesiana.org/pdffile/45-3-4-1.pdf.

12. van de Broek JM, Roy SK, Khan WA, Ara G, Chakraborty B, Islam S, et al. Risk factors for mortality due to shigellosis: a case control study among severely-malnourished children in Bangladesh. Journal of Health Population and Nutrition. 2005: 23 (3).

13. Matthai J, Raju B, Bavdekar A. Chronic and persistent diarrhea in infants and young children: status statement. Indian Pediatrics. 2011; 48 (1): 37-42 [cited 2012 June 6]; 48. Available from: http://medind.nic.in/ibv/t11/i1/ibvt11i1p37.pdf.

14. Guntur. Beberapa faktor yang mempengaruhi kejadian diare rotavirus akut. Medan: Universitas Sumatera Utara; 2008.

15. Hasbullah. Faktor risiko yang mempengaruhi kejadian disentri pada usia balita di Kabupaten Maros tahun 2003 [tesis]. Makassar: Universitas Hasanuddin Makassar; 2003. 